формування й удосконалення як засобами різних предметів, так і через залучення учнів до позаурочної діяльності.

\title{
Література:
}

1. Семенець-Орлова I. Суспільне замовлення на громадянську освіту. URL: https://osvita.ua/school/64003/ (дата звернення: 21.02.2021).

2. Державний стандарт базової середньої освіти. Постанова КМУ № 898 від 30.09.2020 року. URL: https://osvita.ua/legislation/ Ser_osv/76886/ (дата звернення: 21.02.2021).

3. Локшина O.I. Європейська довідкова рамка ключових компетентностей для навчання впродовж життя: оновлене бачення 2018 року // Украӥнський педагогічний журнал. 2019, № 3. С. 21-30.

4. Громадянська освіта: методичний посібник для вчителя. Київ, 2008. Видавництво Етна-1. 194 с.

\section{DOI https://doi.org/10.30525/978-9934-26-041-4-100}

\section{СУЧАСНІ ПІДХОДИ ДО ВИКЛАДАННЯ ІНОЗЕМНИХ МОВ У ЗАКЛАДАХ ВИЩОЇ ОСВІТИ}

\author{
Рябокучма Т. О. \\ стариий викладач \\ Військовий інститут \\ Київського національного університету імені Тараса Шевченка \\ м. Київ, Украӥна \\ Горбаченко А. Л. \\ асистент \\ Киїський національний університет імені Тараса Шевченка \\ м. Київ, Україна
}

На сучасному етапі інтеграції України до світового освітнього простору перед здобувачами освітніх послуг відкривається все більше можливостей для поглиблення знань, що в свою чергу є неможливим без якісного оволодіння іноземною мовою, як інструменту, що здатен забезпечити комунікацію 3 представниками інших країн та культур. Саме тому викладачі закладів вищої освіти (далі 3ВО) посилено працюють над реалізацією Концепції розвитку освіти України на період 2015 - 2025 років, а також над імплементацією новітніх форм, методів, методик, технологій навчання та викладання іноземних мов в освітній процес з метою швидкого оволодіння іноземною мовою [1]. 
Впродовж останніх років проблема пошуку ефективних методик та підходів до викладання іноземних мов набула неабиякої актуальності. Варто зауважити, що це питання розглядається у працях провідних вітчизняних та зарубіжних науковців.

Враховуючи проаналізовані наукові праці, варто виділити такі сучасні підходи до вивчення іноземних мов у ЗВО, як-от:

1. Інноваційний підхід - забезпечує імплементацію сучасних методик та технік в освітній процес.

2. Інформаційний підхід - забезпечує надання здобувачам освітніх послуг точних теоретичних знань.

3. Індивідуальний підхід - забезпечує можливість всебічного розвитку особистості студента, завдяки правильному підбору методів впливу, що допоможуть розкрити індивідуальні нахили та здібності.

4. Когнітивний підхід - забезпечує використання вже набутих знань для отримання нових.

5. Комунікативний підхід - забезпечує краще опанування іноземною мовою в процесі комунікації.

6. Пізнавальний підхід - забезпечує засвоєння основних граматичних конструкцій та лексичних одиниць, що будуть основою в процесі комунікації

7. Тематичний підхід - забезпечує логічність побудови тематичного календаря відповідно до рівня знань студентів.

Варто зауважити, що за умови практичного застосування усіх вищезазначених підходів процес оволодіння іноземною мовою буде цікавий, змістовний, послідовний та цілісний, що в свою чергу урізноманітнить освітній процес та підвищить мотивацію здобувачів освітніх послуг до вивчення іноземних мов [2].

Отже, процес вивчення іноземних мов - це надзвичайно складний механізм, цілісне функціонування якого можливе лише за допомогою впровадження сучасних форм, методів, технік та підходів в освітній проце с. Завдання сучасного викладача закладу вищої освіти полягає у щоденному професійному вдосконаленні 3 метою надання якісної іншомовної підготовки, що в майбутньому забезпечить країну якісними кадрами у всіх стратегічно важливих сферах.

\section{Література:}

1. Концепція розвитку освіти України на період 2015-2025 років : проект / Стратегічна дорадча група «Освіта». URL: http://tnpu.edu.ua/ EKTS/proekt_koncepc.pdf (дата звернення: 12.02.2021).

2. Гарбуз А.В., Хайдарі Н.І. Цілі та особливості проектного навчання в закладі вищої освіти. Подолання мовних та комунікативних бар'єрів: освіта, наука, культура: збірник наук. праць. Київ: НАУ, 2020. C. 52-54. 